\title{
Pelatihan Pembuatan Lampu Penerangan Jalan Umum (PJU) Bertenaga Surya di RW 04 Kelurahan Wonokoyo Kecamatan Kedungkandang Kota Malang
}

\author{
Kris Witono ${ }^{1}$, Satworo Adiwidodo ${ }^{2}$, Agus Hardjito $^{3}$, Agus Setiawan $^{4}$, Sarjiyana $^{5}$ \\ 1,2,3,4,5 Jurusan Teknik Mesin, Politeknik Negeri Malang \\ e-mail: ${ }^{1} k r i s . w i t o n o @$ polinema.ac.id, ${ }^{2}$ satworo.adiwidodo@polinema.ac.id, \\ 33agus.hardjito@polinema.ac.id, ${ }^{4}$ agus.setiawan@polinema.ac.id, ${ }^{5}$ sarjiyana@polinema.ac.id
}

\begin{abstract}
Abstrak
Salah satunya hal terpenting untuk meningkatkan keamanan, khususnya bagi warga di kawasan RW 04 Kelurahan Wonokoyo Kecamatan Kedungkandang Kota Malang adalah penerangan. Instalasi lampu penerangan jalan umum masih minim, sehingga jauh dari memenuhi standar keselamatan. Dengan kondisi seperti diuraikan diatas, maka guna menjamin ketersediaaan lampu penerangan jalan yang aman dan bisa diandalkan, dilakukan pelatihan pembuatan lampu penerangan jalan umum (PJU) bertenaga surya di RW 04 Kelurahan Wonokoyo Kecamatan Kedungkandang Kota Malang. Metode pelaksanaan kegiatan meliputi: survey lokasi, identifikasi dan solusi masalah, perencanaan kegiatan, perhitungan kebutuhan bahan dan peralatan, pelatihan pembuatan tiang lampu PJU bertenaga surya dan pemasangannya. Hasil kegiatan antara lain peningkatan pengetahuan dan ketrampilan warga di bidang fabrikasi dan instalasi lampu PJU bertenaga surya, terpasangnya 2 buah Lampu PJU Bertenaga Surya, menggunakan lampu LED $60 \mathrm{~W}$ bertegangan DC 12V, Panel Surya $50 \mathrm{WP}$, Solar Charger ontroller kapasitas maks 10 A, dan Baterai VRLA 65 Ah, yang berdampak pada peningkatan keamanan lingkungan dan aktivitas warga pada malam hari di lingkungan $R W 04$ Kelurahan Wonokoyo Kecamatan Kedungkandang Kota Malang.
\end{abstract}

Keywords - PJU, bertenaga surya, LED

\section{PENDAHULUAN}

$\mathrm{R}$ ukun Warga (RW) 04 Kelurahan Wonokoyo Kecamatan Kedungkandang Kota Malang terletak pada daerah yang relatif lebih tinggi dibandingkan dengan wilayah lain di kota Malang. Meskipun begitu wilayah ini termasuk wilayah timur yang berkembang di kota Malang karena dekat dengan GOR Ken Arok, Kantor Pemerintah Kota Malang Terpadu, akses jalan tol, Pasar Gadang, Terminal Hamid Rusdi Gadang. Dengan semakin banyaknya pendatang maka ada ekses baik yang positif maupun negatif. Diantara ekses negatifnya adalah faktor keamanan. Salah satu hal terpenting untuk meningkatkan keamanan, khususnya bagi warga di kawasan RW 04 Kelurahan Wonokoyo Kecamatan Kedungkandang Kota Malang adalah penerangan. Instalasi lampu penerangan jalan umum sejatinya telah ada namun masih minim, akan mudah memancing terjadinya tindak kejahatan. Penginstalan lampu penerangan jalan yang ala kadarnya, yang hanya di tautkan tembok atau di pohon dengan seutas kawat sehingga sangat berbahaya jika terjadi short circuit khususnya pada saat memasuki musim hujan seperti sekarang ini.

Dengan kondisi seperti diuraikan diatas, maka untuk meningkatkan ketrampilan warga RW 04 Kelurahan Wonokoyo Kecamatan Kedungkandang Kota Malang dan guna menjamin ketersediaaan lampu penerangan jalan yang aman dan bisa diandalkan, dilakukan pelatihan pembuatan lampu penerangan jalan umum. Sebelum proses pembuatan lampu penerangan jalan dilakukan pelatihan singkat tentang pembuatan tiang 
lampu PJU bertenaga surya dan pemasangannya oleh pengajar Politeknik Negeri Malang.

\section{SOLUSI}

Lampu Penerangan Jalan Umum (PJU) adalah bagian dari bangunan pelengkap jalan yang dapat dipasang di kiri atau kanan jalan dan atau di tengah (di bagian median jalan) yang digunakan untuk menerangi jalan maupun lingkungan di sekitar jalan.

Lampu Penerangan Jalan Umum Bertenaga Surya merupakan sebuah alternatif yang murah dan hemat untuk digunakan sebagai sumber listrik penerangan karena menggunakan sumber energi gratis dan tak terbatas dari alam yaitu energi matahari. Lampu penerangan jalan umum bertenaga surya menggunakan panel surya dengan umur pakai yang dapat mencapai 25 tahun, yang berfungsi menerima cahaya (sinar) matahari yang kemudian diubah menjadi listrik melalui proses photovoltaic. Kemudian disimpan di baterai sehingga tidak memerlukan suplai dari PLN, secara otomatis dapat mulai menyala pada sore hari dan padam pada pagi hari dengan perawatan yang mudah dan efisien selama bertahun tahun. Secara keseluruhan sistem ini dirancang untuk penyediaan cahaya penerangan umum dengan sumber energi terbarukan, bebas biaya perawatan, dan berumur ekonomis lama.

Penerangan jalan bertenaga surya umumnya menggunakan lampu LED (Light Emitting Diode) memiliki daya yang lebih sedikit dan efisien. Penggunaan lampu LED jenis hi-power yang sangat terang, hemat energi, dan tahan lama. Masa pemakaian Lampu LED bisa mencapai 50.000 jam dengan sumber daya DC (Direct Current). Lamanya interval penggantian lampu berarti juga mengurangi frekuensi dan menghemat biaya operasional pemeliharaan untuk ongkos jasa penggantian bola lampunya. Baterai yang digunakan untuk lampu penerangan jalan umum bertenaga surya adalah baterai bebas perawatan (maintenance free) jenis VRLA dan tipe Deep Cycle. Dengan menggunakan perangkat ini, sudah memiliki sumber energi sendiri tanpa ketergantungan dengan pihak lain, hemat BBM, dan ramah lingkungan. Lampu penerangan jalan umum bertenaga surya beroperasi secara mandiri dan tidak memerlukan kabel jaringan antar tiang sehingga instalasinya menjadi sangat mudah, praktis, ekonomis, dan tentunya dapat terhindar dari pemadaman listrik. Dengan sistem pemasangan yang cepat dan mudah, lampu penerangan jalan umum bertenaga surya dapat menjadi solusi yang cepat dalam mengatasi kebutuhan penerangan jalan umum.

Pertimbangan-pertimbangan

menggunakan lampu penerangan jalan umum bertenaga surya berbasis LED:

1. Daya tahan modul solar panel dan LED

2. Bersifat mandiri, tanpa jaringan tenaga listrik

3. Menggunakan energi matahari

4. Ramah lingkungan

5. Instalasi sangat mudah

6. Hemat biaya perawatan

7. Mudah dipindahkan

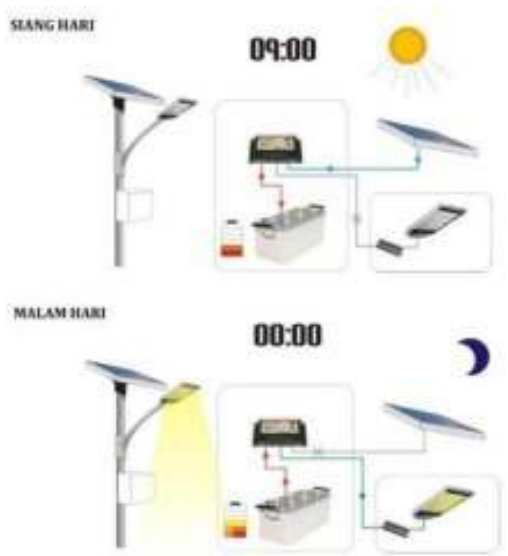

Gambar 1. Prinsip Kerja PJU Bertenaga Surya

Penerapan lampu penerangan jalan umum bertenaga surya bisa berupa: lampu jalan, lampu taman, lampu dermaga, lampu lapangan parkir, lampu jalan raya terpencil, lampu jalan pedesaan, lampu penerangan wisata, lampu jalan perkebunan, lampu jalan pertambangan, dan lain-lain.

Prinsip kerja lampu penerangan jalan umum bertenaga surya dapat diuraikan sebagai berikut:

Pada siang hari, sinar matahari dikonversi menjadi arus listrik oleh panel surya. Arus listrik tersebut dialirkan ke baterai melalui SCC (Solar Charge Controller) sebagai 
regulator arus dan menjaga agar tidak terjadi over discharge pada baterai. Pada malam hari, lampu akan menyala dengan mengambil energi listrik yang disimpan pada baterai ketika siang hari. Arus listrik dari baterai ke lampu mengalir melalui SCC agar arus listrik tetap stabil. Lampu penerangan yang dimaksud adalah suatu unit lengkap yang terdiri dari sumber cahaya (lampu/luminer), elemen-elemen optic (pemantul/reflector, pembias/refractor, penyebar/diffuser). Elemen-elemen elektrik (konektor ke sumber tenaga/power supply. dll.), struktur penopang yang terdiri dari lengan penopang, tiang penopang vertikal dan pondasi tiang lampu.

Dalam perencanaan instalasi penerangan jalan haruslah semestinya dengan standar dan ketentuan yang telah berlaku. Di Indonesia, ketentuan ini dinamakan SNI (Standar Nasional Indonesia). Tiang merupakan komponen yang digunakan untuk menopang lampu. Beberapa jenis tiang yang digunakan untuk lampu jalan adalah tiang besi dan tiang octagonal. Berdasarkan Standar Nasional Indonesia (SNI 7391:2008) Spesifikasi Penerangan Jalan Di Kawasan Perkotaan, tiang lampu jalan dapat dibagi menjadi 3, yaitu lengan tunggal, lengan ganda, dan tanpa lengan.

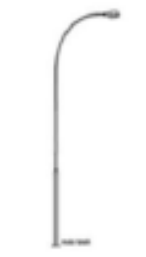

Lengan tunggal

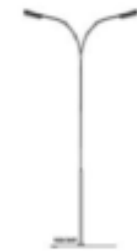

Lengan ganda

Luk Lengan Tiang Lampu Jalan (SNI 7391:2008)

Sedangkan jenis sumber cahaya, lampu penerangan jalan umum dapat pula dibedakan atas 3 (tiga) macam yaitu lampu merkuri, lampu sodium, dan lampu LED.
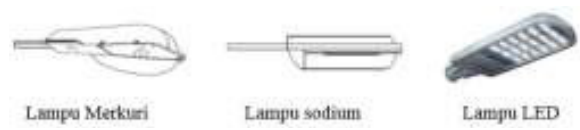

Gambar 3. Lampu Merkuri, Lampu Sodium, Lampu LED

Untuk menentukan sudut kemiringan lengan tiang lampu $(\alpha)$ agar titik penerangan mengarah ke tengah tengah jalan, dapat dihitung menggunakan Pers. (1):

$\cos \alpha=\frac{h}{t}$

Sedangkan harga $t$ dihitung menggunakan Pers. (2).

$t=\sqrt{h^{2}+c^{2}}$

Pers. (2)

Dimana,

$\mathrm{h}=$ tinggi tiang

$\mathrm{t}=$ jarak lampu ke tengah-tengah jalan

$\mathrm{c}=$ jarak horizontal lampu dengan tengah jalan

$\mathrm{W} 1=$ tiang ke ujung lampu

$\mathrm{W} 2=$ jarak horizontal lampu ke ujung jalan

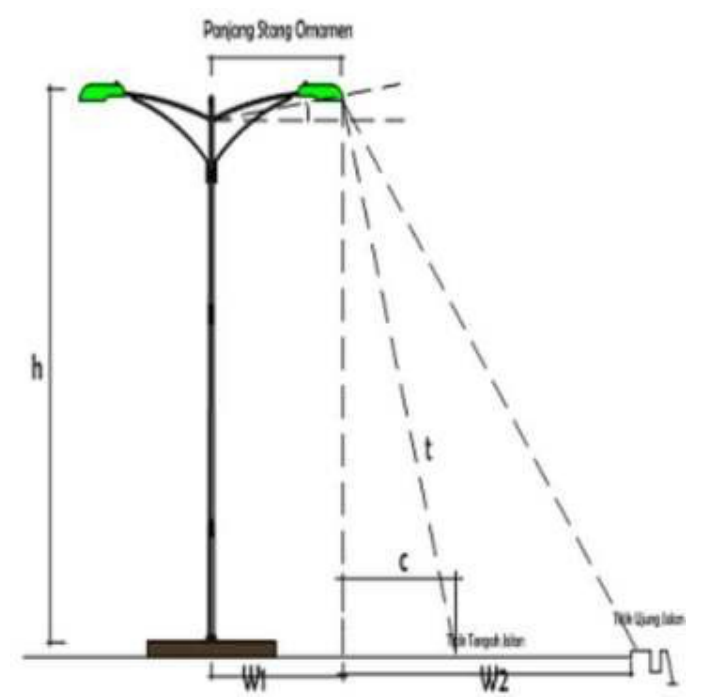

Gambar 4. Penentuan sudut kemiringan stang ornamen terhadap lebar jalan (SNI 7391, 2008)

Perhitungan kapasitas dan kemampuan komponen- komponen lampu PJU berbasis solar system menurut (Suriadi,\& Syukri, 2010) terdiri dari:

a. Panel surya

Perhitungan kapasitas panel surya dapat dihitung menggunakan Pers. (3).

$P_{\text {panel surya }}=\frac{E T}{\text { isolasi matahai }} * 1,1$

Dimana $P_{\text {panel surya }}$ adalah daya panel (Wp), ET adalah penggunaan daya (Wh), dan isolasi matahari adalah waktu efektif sinal matahari per hari

b. Battery 
c. Kapasitas battery dapat dihitung dengan menggunakan Pers. (4)

$A h=\frac{E T}{V_{S}}$

Pers. (4)

Dimana Ah adalah daya battery (Ah), Vs adalah teganggan battery yang digunakan (volt). Selain itu kapasitas battery juga harus mempertimbangkan deep of discharge (DOD) sebesar $80 \%$ yang dapat dihitung dengan menggunakan Pers. (5).

$C b=\frac{A h}{D O D}$

Dimana $\mathrm{Cb}$ adalah daya battery dengan memepertimbangkan DOD (Ah), Ah adalah daya battery sebelum mempertimbangkan DOD (Ah) dan DOD bernilai $80 \%(0,8)$

d. Change Control

Pers. (6) dapat digunakan untuk perhitungan kapasitas change control.

$I_{\text {maks }}=\frac{P_{\text {maks }}}{V_{s}}$

Dimana $I_{\text {maks }}$ adala kapasitas arus charge control (A), P $P_{\text {maks }}$ adalah kapasitas dari panel surya (W), dan $V_{S}$ adalah tegangan panel surya $(\mathrm{V})$.

Solusi yang ditawarkan untuk mengatasi permasalahan mitra adalah sebagai berikut:

1. Perlu adanya identifikasi SDM warga di RW 04 Kelurahan Wonokoyo Kecamatan Kedungkandang Kota Malang

2. Perlu adanya pelatihan pembuatan tiang lampu PJU bertenaga surya

3. Perlu adanya pelatihan pembuatan dan instalasi lampu PJU bertenaga surya

\section{METODE PELAKSANAAN}

Metode yang dilakukan dalam kegiatan PKM ini antara lain:

1. Survey lapangan untuk mempelajari permasalahan yang ada dan selanjutnya memberikan penawaran tentang Pelatihan Pembuatan Lampu Penerangan Jalan Umum (PJU) Bertenaga Surya.

2. Kegiatan berikutnya adalah penyusunan proposal kegiatan yang diusulkan kepada Unit
Pelaksana Teknis P2M Politeknik Negeri Malang.

3. Setelah mendapat persetujuan, dilaksanaan kegiatan pelatihan dengan produk Lampu Penerangan Jalan Umum (PJU) Bertenaga Surya

Alur pelaksanaan $\mathrm{PkM}$ ini dilakukan melalui beberapa tahapan yang digambarkan dalam diagram alir sebagai berikut:

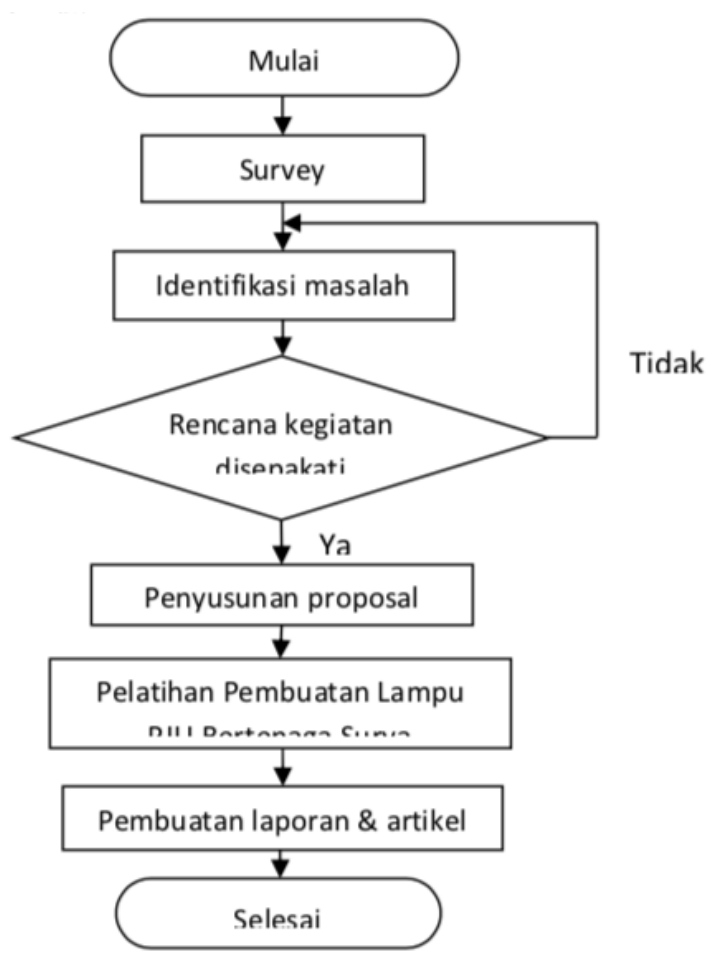

Gambar 5. Diagram alir pembuatan lampu PJU

Penjelasan dari diagram alir kegiatan ini:

1. Mulai

Tahap ini merupakan tahap awal kegiatan dimulai dengan mencari lokasi kegiatan pengabdian.

2. Survei Lapangan

Dalam tahap ini mempelajari daerah yang dituju terutama berkaitan dengan penentuan kelayakan kegiatan dengan harapan kegiatan dapat mencapai sasaran.

3. Identifikasi permasalahan

Setelah memastikan lokasi kegiatan dalam tahap ini tim pengabdian mengidentifikasi kebutuhan yang menjadi permasalahan dari lokasi kegiatan yang akan dipecahkan. 
4. Setelah melakukan identifikasi permasalahan penulis bersama tim mengajukan usulan secara non formal kepada Ketua RW 04 Kelurahan Wonokoyo Kecamatan Kedungkandang Kota Malang, selanjutnya setelah mencapai kesepakatan maka segera dilakukan penyusunan prosposal kegiatan yang diajukan ke pihak sumber dana dalam hal ini adalah institusi Politeknik Negeri Malang melalui P2M.

5. Penyusunan proposal

Dalam tahap ini penulis mengajukan usulan kegiatan beserta rencana anggaran yang dibutuhkan.

6. Kegiatan Pelatihan Dan Pembuatan Lampu PJU Bertenaga Surya

Dalam proses selanjutnya setelah proposal disetujui maka membuat rancangan kegiatan, selanjutnya survey bahan serta memulai kegiatan pelatihan yang dilaksanakan oleh pengajar dari Politeknik Negeri Malang

7. Pembuatan laporan dan artikel Dalam tahap ini dilakukan penyusunan laporan pertanggung jawaban kegiatan. Dalam tahap ini juga dilakukan penulisan artikel dari laporan kegiatan untuk diterbitkan oleh UPT P2M Politeknik Negeri Malang.

8. Selesai.

Dalam tahap ini dilakukan penyusunan laporan pertanggung jawaban kegiatan.

\section{HASIL DAN MANFAAT}

Hasil yang diperoleh dari kegiatan PKM adalah:

1. Perhitungan Tiang Lampu Penerangan Jalan Umum Bertenaga Surya

Hasil perhitungan sudut kemiringan lengan tiang lampu $(\alpha)$, dengan tinggi tiang (h) setinggi 6 meter dan jarak horizontal lampu dengan tengah jalan (c) selebar 5 meter, adalah sebesar 39,80 .

2. Perhitungan Lampu Penerangan Jalan Umum Bertenaga Surya

Hasil perhitungan didapatkan Lampu PJU bertenaga surya yang dipasang menggunakan output berupa lampu dc LED dengan daya sebesar $60 \mathrm{~W}-12 \mathrm{~V}$, dengan asumsi pemakaian selama 12 jam/hari. Maka daya yang diperlukan untuk menghidupkan lampu dc per tiap harinya adalah sebesar 720 Wh. Berdasarkan perhitungan kapasitas dan kemampuan komponen, untuk dapat menghidupkan lampu dc sebesar 720 Wh (termasuk cadangan daya), maka diperlukan panel surya $50 \mathrm{Wp}$, battery $65 \mathrm{Ah}$, dan charge control $10 \mathrm{~A}$.

3. Pembelian bahan Lampu Penerangan Jalan Umum Bertenaga Surya
a. Tiang Lampu
b. Lampu LED 60 W bertegangan DC $12 \mathrm{~V}$
c. Panel Surya $50 \mathrm{WP}$
d. Solar charger controller kapasitas maks $10 \mathrm{~A}$
e. Baterai VRLA $65 \mathrm{Ah}$

4. Pelatihan Lampu Penerangan Jalan Umum Bertenaga Surya

Dari pelaksanaan kegiatan Pelatihan Lampu Penerangan Jalan Umum Bertenaga Surya yang telah dilakukan di RW 04 Kelurahan Wonokoyo Kecamatan Kedungkandang Kota Malang, warga terlihat telah memahami konsep dasar dalam penerangan jalan serta penerapan dan pemanfaatannya dalam kehidupan sehari- hari melalui berbagai pamaparan materi yang disampaikan. Dalam pemaparan materi yang dilakukan, disampaikan tentang pentingnya sumber energi terbarukan dan dampak negatif dari penggunaan energi tak tebarukan yang selama ini sebagian besar dilakukan oleh PLN 
untuk menghasilkan energi listrik. Selain itu disampaikan juga kelebihan penggunaan PJU bertenaga surya dibandingkan lampu PJU konvensional diantaranya yaitu:

- Terang dan tahan lama

- Hemat energi tanpa biaya listrik

- Ramah lingkungan tanpa polusi

- Cepat dan mudah dalam pemasangan

- Perawatan mudah

Materi selanjutnya berisi penjelasan pada warga mengenai prinsip kerja lampu PJU bertenaga surya dan peralatan yang dibutuhkan untuk memasang unit lampu PJU bertenaga surya. Warga juga diberitahu agar melakukan pembersihan rutin minimal 2 kali setahun agar tidak terjadi penumpukan debu pada panel surya PJU, yang dapat mengakibatkan kurangnya daya yang dihasilkan oleh panel surya.

5. Pembuatan tiang lampu penerangan jalan umum bertenaga surya

Pembuatan tiang lampu PJU bertenaga surya dilakukan di salah satu rumah warga, setelah sebelumnya diadakan pemaparan materi tentang lampu penerangan jalan umum bertenaga surya dan teknik-teknik fabrikasi tiang lampu PJU. Peralatan untuk pembuatan tiang lampu (gerinda, gergaji besi, dll) dan sumber listrik yang digunakan, disediakan oleh warga setempat sebagai wujud peran serta dan antusiasme warga terhadap kegiatan ini.

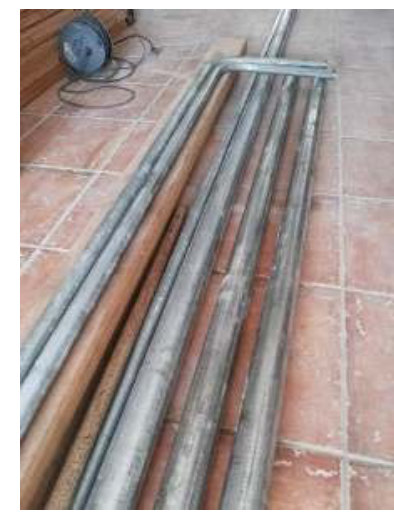

Gambar 6. Bahan Tiang lampu PJU

6. Instalasi dan Pemasangan lampu penerangan jalan umum bertenaga surya

Pemasangan lampu PJU bertenaga surya dilakukan oleh tim pelaksana PKM dan dibantu oleh warga sekitar, setelah sebelumnya dilakukan penyerahan peralatan tiang dan lampu PJU bertenaga surya kepada Ketua RW 04 Kelurahan Wonokoyo Kecamatan Kedungkandang Kota Malang. Sebelum proses pemasangan dilakukan terlebih dahulu dilakukan pengarahan kepada warga yang akan membantu mengenai lokasi pemasangan lampu berikut prosedur pemasangan dan keselamatan oleh Ketua RW 04 Kelurahan Wonokoyo Kecamatan Kedungkandang Kota Malang bersama tim pelaksana PKM. Jumlah total lampu yang dipasang adalah 2 unit.

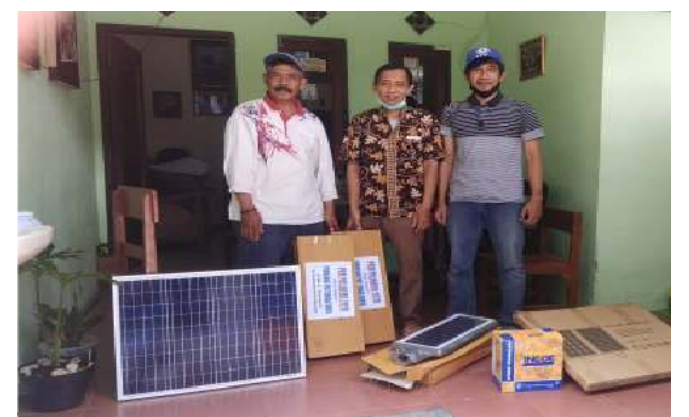

Gambar 7. Penyerahan Peralatan Pada Ketua $R W$ 


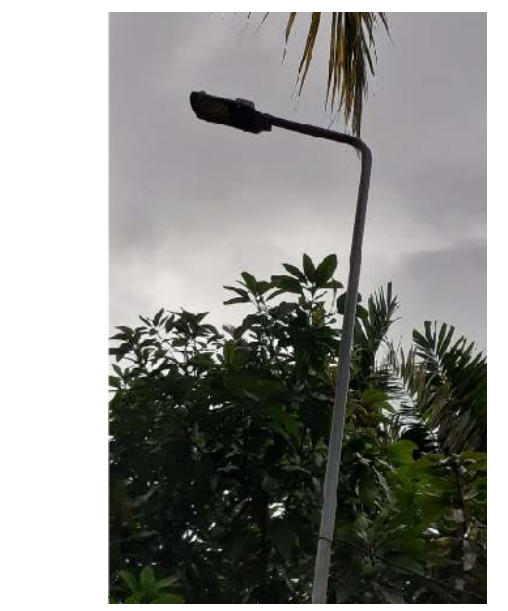

Gambar 8. Pemasangan Lampu PJU

Bertenaga Surya

4. KESIMPULAN

Kesimpulan dari Pelatihan Pembuatan Lampu Penerangan Jalan Umum (PJU) Bertenaga Surya di RW 04 Kelurahan Wonokoyo Kecamatan Kedungkandang Kota Malang ini adalah:

1. Peningkatan pengetahuan dan ketrampilan warga RW 04 Kelurahan Wonokoyo Kecamatan Kedungkandang Kota Malang di bidang fabrikasi dan instalasi lampu PJU bertenaga surya.

2. Terpasangnya 2 buah Lampu PJU Bertenaga Surya yang aman dan bisa diandalkan, dimana masing-masing memerlukan tiang lampu setinggi $6 \mathrm{~m}$, lampu LED $60 \mathrm{~W}$ bertegangan DC $12 \mathrm{~V}$, Panel Surya $50 \mathrm{WP}$, Solar charger controller kapasitas maks 10 A, dan Baterai VRLA 65 Ah. Hal tersebut berdampak pada peningkatan keamanan lingkungan dan aktivitas warga pada malam hari di lingkungan RW 04 Kelurahan Wonokoyo Kecamatan Kedungkandang Kota Malang

\section{DAFTAR PUSTAKA}

[1] Anhar, W., Basri, Amin, M., Randis, \& Sulistyo, T. 2018. Perhitungan Lampu Penerangan Jalan Berbasis Solar System. Jurnal Sains Terapan, 4 (1), 33-36. DOI: https://doi.org/10.32487/jst.v4i1.449.

[2] Anhar, W., Akbar, S., Basri, Laksito, A., \& Huda. N. 2019. Penerapan
Lampu Penerangan Jalan Umum Berbasis Solar System di RT 50 Kelurahan Sepinggan Kota Balikpapan. Jurnal KACANEGARA Volume 2, Nomor 2, Juli $2019 . \quad$ DOI:

10.28989/kacanegara.v2i2.433

[3] Azzahra, S., Christiono, Samsurizal, Fikri, M., Ratnasari, T., Putra, R. P., dan Damiri, D. J., 2019. Pemasangan Lampu Jalan Berbasis Solar Cell untuk Penerangan Jalan di Desa Cilatak Ciomas. Terang: Jurnal Pengabdian Pada Masyarakat Menerangi Negeri Vol. 1, No. 2, Juli 2019.

DOI: https://doi.org/10.33322/terang.v1i2. $\underline{486}$

[4] Hendarto, D. 2018. Perencanaan Pemasangan Penerangan Jalan Umum Berbasis Solarcell (PJUBS) Di Desa Cibadak. Prosiding Hasil Penelitian Dosen Universitas Ibn Khaldun Bogor Tahun 2018, 19-30. http://pkm.uika-

bogor.ac.id/index.php/prosiding/inde $\underline{x}$

[5] Khoiriyah, Umi. 2018. Perencanaan Dan Analisis Pembiayaan Penerangan Jalan Umum (PJU) (Studi Kasus: Jl. Tangkil-Ngeluk Kec. Gesi Kab. Sragen). http://eprints.ums.ac.id/61554/

Diakses tanggal 02 September 2020 .

[6] Suhardi, D. 2014. Prototipe Controller Lampu Penerangan LED (Light Emitting Diode) Independent Bertenaga Surya. Jurnal Gamma, 10 (1), 116-122.

[7] Suriadi, \& Syukri, M. 2010. Perencanaan Pembangkit Listrik Tenaga Surya (PLTS) Terpadu Menggunakan Software PVSYST Pada Komplek Perumahan Di Banda Aceh. Jurnal Rekayasa Elektrik, 9 (2), 77-80.

[8] Winardi, B., \& Nugroho, A. 2007. Perencanaan Penataan Lampu Penerangan Jalan Umum (LPJU) Sebagai Upaya Efisiensi Tagihan Rekening Listrik Kecamatan Suruh Kabupaten Semarang UPJ Salatiga. 
Transmisi-Jurnal Teknik Elektro, 9

(2), 138-144. 